\title{
THE EFFECTS OF CHLORAMPHENICOL, NALIDIXIC ACID AND PENICILLIN ON THE GROWTH AND DIVISION OF SWARMING CELLS OF PROTEUS MIRABILIS
}

\author{
Judith P. ARMtage, R. J. Rowbury and D. G. Smith \\ Department of Botany and Microbiology, University College London, London WC1E 6BT
}

\section{Plates XXVI AND XXVII}

PROTEUS MIRABILIS growing on the surface of suitable agar media undergoes a cycle of differentiation that leads to the well-known and often troublesome phenomenon of zonal swarming colonies (Smith, 1972). The actively motile swarm cells which spread out across the agar surface are greatly elongated filaments (up to $80 \mu \mathrm{m}$ ) possessing large numbers of flagella and regularlyspaced nuclear bodies. After an active period of swarming, the filaments divide into shorter rods and the process of elongation and swarming is repeated.

Filament formation can be produced in bacteria by a variety of environmental conditions, but Proteus is virtually unique in that the process occurs under apparently normal conditions and in a rhythmical fashion. The situation can be described as an alternate switching off and on of the cell-division process and greatly increased synthesis of flagellin while cell elongation and the segregation of nuclear bodies are not affected. It is possible, therefore, that a study of this phenomenon might allow further understanding of the control of bacterial cell division.

In this paper we report an investigation into the effects of three antibiotics on the growth of individual long swarming filaments and their division into short rods. Antibacterial agents affecting different aspects of metabolism were used: chloramphenicol to inhibit protein synthesis, nalidixic acid to inhibit DNA synthesis and penicillin to inhibit murein synthesis. Individual cells were observed on the surface of thin layers of agar containing the inhibitory agent in view of the difficulty of obtaining homogeneous populations of swarm cells in suspension.

\section{MATERIALS AND METHODS}

The strain of Proteus mirabilis was an isolate from University College Hospital, London. Stock cultures were maintained on nutrient agar slopes. Oxoid Nutrient Agar was used for growth on solid media and Oxoid Nutrient Broth no. 2 for liquid culture.

The antibacterial agents were nalidixic acid (Winthrop Products Co., Surbiton, Surrey), chloramphenicol (Sigma London, Kingston upon Thames, Surrey) and benzylpenicillin (Glaxo Laboratories, Greenford, Middlesex).

\section{Studies with light microscopy}

Nutrient agar plates, after drying for $15 \mathrm{~min}$. at $60^{\circ} \mathrm{C}$, were centrally seeded with a loopful of an 18 -hour broth culture of $P$. mirabilis and incubated for 18 -hour at $30^{\circ} \mathrm{C}$, the optimal

Received 25 Jan. 1974; accepted 13 Mar. 1974.

J. MED. MICROBIOL.—VOL. 7 (1974) 
swarming temperature for this strain. The long cells were harvested from the edge of the colony by the method of Jones and Park (1967). The central non-swarming part of the colony was cut out and the long cells outside this area were washed off with broth to form a thick suspension.

The antibiotic to be used was added to melted nutrient agar at about $40^{\circ} \mathrm{C}$ to give the required final concentration. The final concentrations used in all cases were sufficiently low to be non-lethal but sufficiently high to be inhibitory: nalidixic acid $15 \mu \mathrm{g}$ per ml, chloramphenicol $200 \mu \mathrm{g}$ per $\mathrm{ml}$, and penicillin 5 units per $\mathrm{ml}$.

A metal ring of $1.5 \mathrm{~cm}$ diameter, previously fixed to a glass slide with Laktoseal (Searle and Co., High Wycombe, Bucks), was filled with the antibiotic agar to a depth of about $1 \mathrm{~mm}$ and allowed to set. A drop of the suspension of long cells was placed on the agar and a coverslip was placed on to the ring, thus giving a closed system that could resist drying for several hours. This preparation was examined with a Zeiss photomicroscope using phasecontrast optics and a heated stage at $30^{\circ} \mathrm{C}$. Photographs were taken every $15 \mathrm{~min}$., the same field being kept under observation for the duration of the experiment (about 5 hours).

\section{Electronmicroscopy}

Electron microscopy was used to examine and compare effects of penicillin on the long swarm cells and on exponential cells from liquid culture. In the latter case an 18-hour broth culture was resuspended in nutrient broth and grown up to exponential phase. A suspension of long cells was adjusted to the same optical density. Penicillin at a final concentration of 15 units per $\mathrm{ml}$ was added to each suspension and samples were taken for electron microscopy every $30 \mathrm{~min}$. for 3 hours.

The samples were pre-fixed with osmium tetroxide and then fixed by the method of Kellenberger, Ryter and Séchaud (1958), dehydrated through a tertiary butyl alcohol series and embedded in Araldite. Thin sections were stained for $20 \mathrm{~min}$. with saturated ethanolic uranyl acetate and examined in a Siemens Elmiskop I electron microscope.

\section{RESULTS}

The division time of untreated long cells determined by time-lapse photomicrography was about $25 \mathrm{~min}$.; this is the time taken for the number of shorter cells derived from the single initial long cell to double. This is of the same order as the division time of short cells in an exponentially-growing broth culture.

The breakdown of the untreated long swarming cell appeared to take place initially at only one or two sites, not simultaneously at all potential division sites (fig. 1). Nuclear bodies were clearly seen by phase-contrast and electron microscopy (fig. 7) to be evenly spaced along the length of the long cell, and division could be seen to take place between them.

\section{Inhibition of DNA synthesis}

When DNA synthesis was inhibited by nalidixic acid, divisions of the long swarming cells of Proteus continued as in untreated cells for about 2-2.5 hours and then stopped (fig. 2). The long cell appeared to divide into its potential number of short cells with one to three nuclear bodies, and thereafter there was some elongation of the cells but no subsequent division. In contrast, when normal cells were treated with nalidixic acid they then only divided once at most, depending on the stage in the growth cycle, and they divided no more after about $20 \mathrm{~min}$. although they continued to grow in length because protein synthesis is not affected by nalidixic acid. 

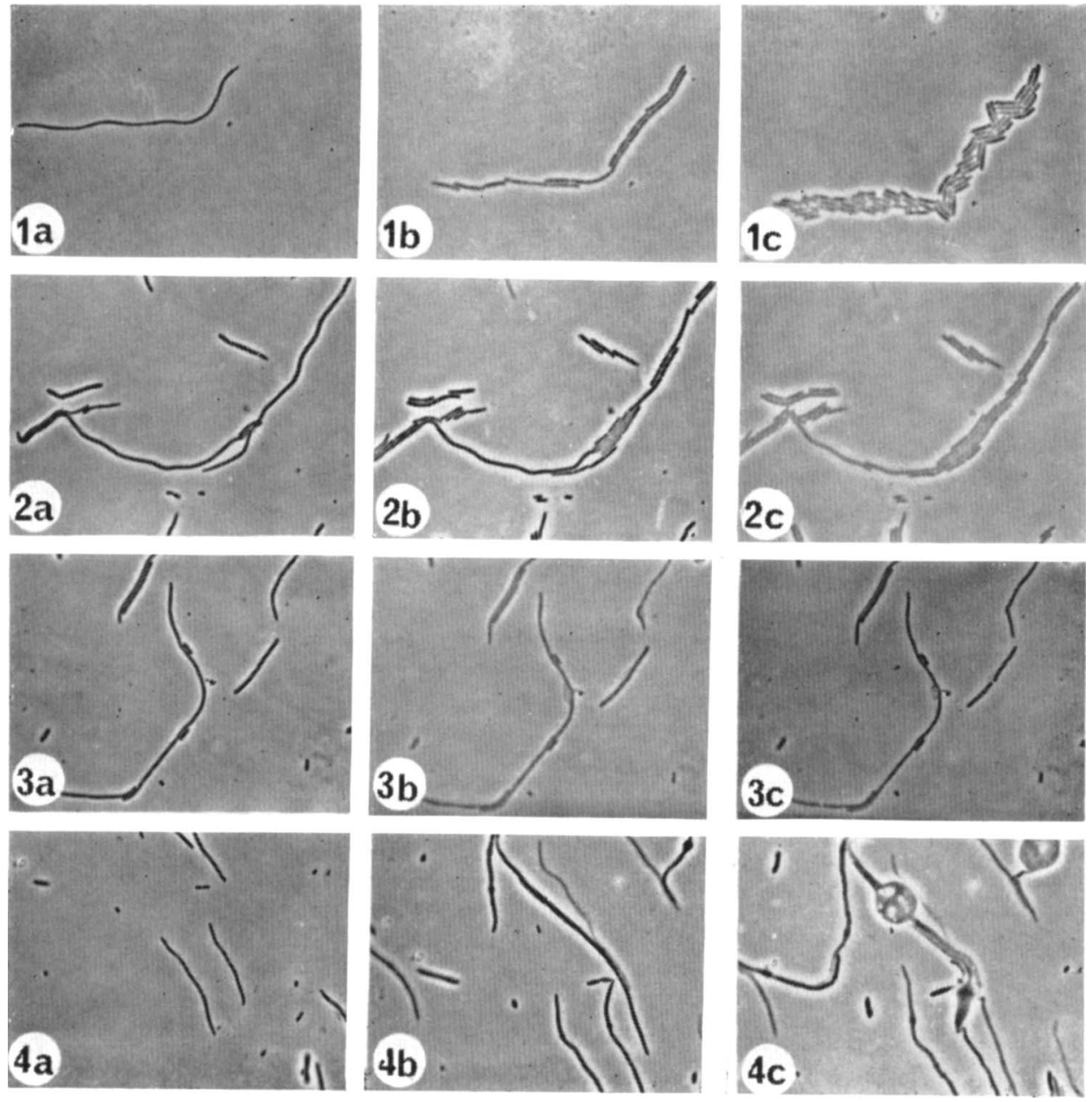

FIG. 1.-Division of Proteus mirabilis swarmers on agar without added antibiotics.

FIg. 2. -Effect of nalidixic acid (15 $\mu \mathrm{g}$ per ml) on Proteus swarmers.

Fig. 3.-Effect of chloramphenicol $(200 \mu \mathrm{g}$ per ml) on Proteus swarmers.

FIG. 4.--Effect of penicillin ( 15 units per $\mathrm{ml}$ ) on Proteus swarmers.

(FIGs. 1-4: $a, 0$ min.; $b, 90 \mathrm{~min} . ; c, 180 \mathrm{~min}$.) All $\times 640$. 
Growth AND Division of Proteus mirabilis
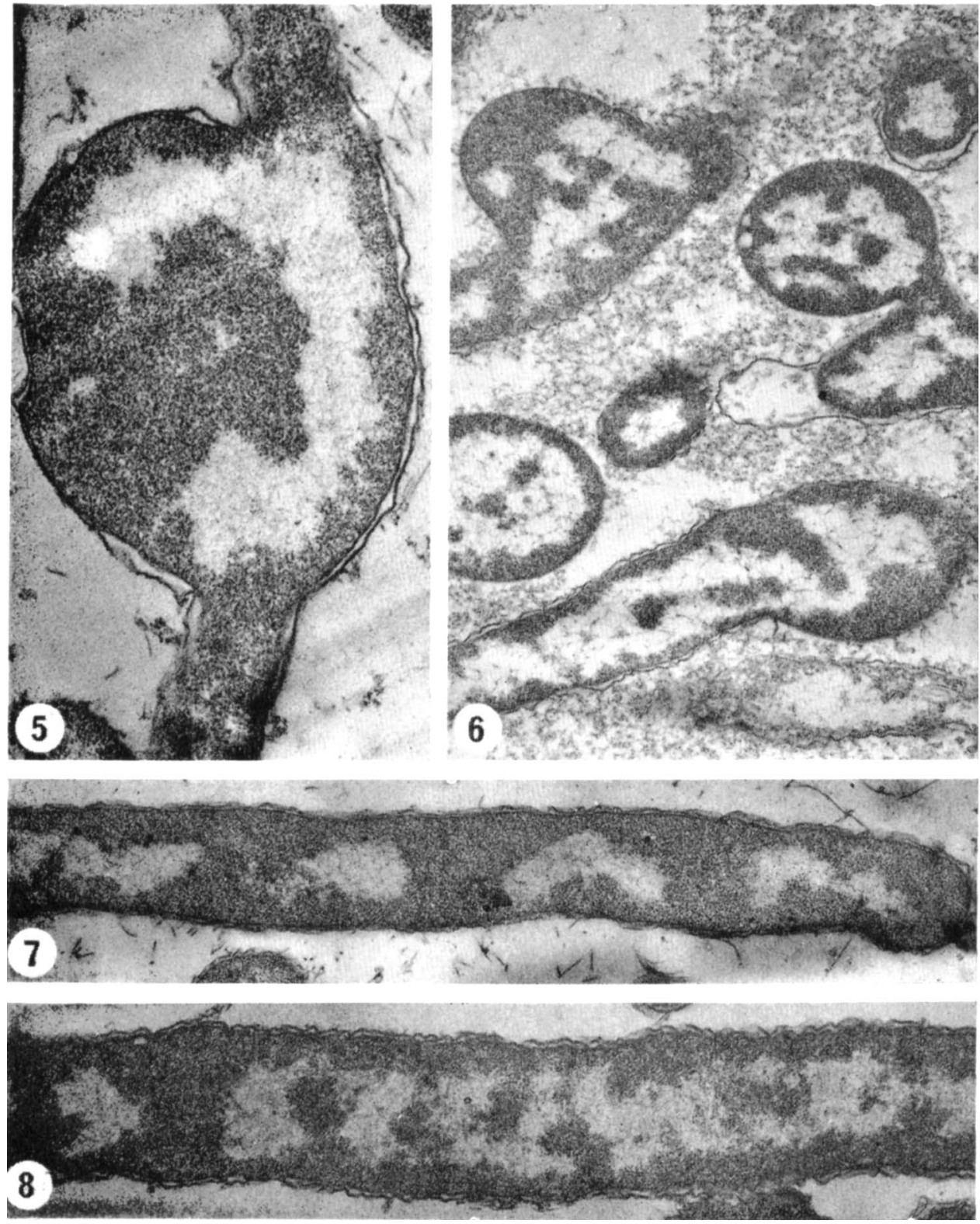

Fig. 5.-Electronmicrograph of penicillin-treated (15 units per $\mathrm{ml}, 120 \mathrm{~min}$.) Proteus swarmers. $\times 39,600$.

FIG. 6.-Electronmicrograph of thin sections of penicillin-treated (15 units per $\mathrm{ml}, 180 \mathrm{~min}$.) Proteus swarmers. $\times 21,600$.

FIG. 7.-Thin section of untreated Proteus swarmer. $\times 32,300$.

FIG. 8. - Thin section of penicillin-treated (15 units per ml, $90 \mathrm{~min}$.) Protets swarmer. $\times 32,300$. 
The nuclear bodies were visible throughout the period of inhibition of DNA synthesis.

\section{Inhibition of protein synthesis}

When protein synthesis was inhibited in long swarming cells by the addition of chloramphenicol there was limited division (fig. 3). The number of divisions varied from experiment to experiment, perhaps depending on the precise stage of the swarming cell under examination. In no case, however, did the long cell divide into its potential number of small cells as in cells treated with nalidixic acid. In most cells examined there were only about two or three divisions and division halted completely in 45-60 min.

Because protein synthesis had been inhibited and cell growth stopped, it was often difficult to be certain that a division had been completed as the cells tended to stay in contact rather than grow past each other.

\section{Inhibition of murein synthesis}

Division of the long swarming cells ceased immediately on transfer to penicillin agar but growth (elongation) of the cells continued normally for 30-45 min. After this time, elongation continued but the cell wall began to be obviously affected. The cells became fatter and bulges appeared, usually two or more per cell. After about $60 \mathrm{~min}$. the nuclear material became much less distinct and apparently spread diffusely, through the cell. After exposure to penicillin for about 2 hours, the whole cell wall was distorted; some of the bulges were unusually large and increased in size until finally bursting (figs. 4 and 6).

Electronmicroscopy revealed that the very large bulges had intact cell walls (fig. 5) and that there were a limited number of bulges per cell, these being perhaps the most active regions of murein synthesis and the first potential division sites. These would thus be the most weakened and distorted.

The dispersion of the nuclear material was also confirmed by electron microscopy (fig. 8). Visually there appeared to be no reduction in the relative amount of nuclear material, indicating perhaps that the amount of DNA synthesised under these conditions did not change, but no quantitative evidence is available.

\section{DisCUSSION}

Division of a swarming filament of $P$. mirabilis into short cells in the absence of antibacterial agents was asynchronous; this suggests that either some potential division sites bind the division components more readily than others or that septa were already partially formed at some sites. The initial septa seemed to be most readily formed at central sites in the filaments.

Our observations on the division of swarming filaments and the effects of antibacterial agents on the process are summarised in fig. 9. There are a number of possible lesions that can inhibit cell division. Our findings make it possible to rule out some of these as causes of filamentation in Proteus.

First, inhibition of DNA synthesis or of nuclear-body segregation generally 
prevents cell division, but not elongation in enterobacteria (Helmstetter and Pierucci, 1968). In Proteus swarmers, however, the nuclear bodies are evenly spaced along the filaments and appear to have been replicated synchronously. The failure of nalidixic acid to prevent division of the filaments for $2-2.5 \mathrm{~h}$ confirms that DNA replication has been normal during the formation of these filaments and rules out the possibility of some subtle abnormality of segregation.

Second, an abnormality in initiation of division would cause filament formation (Mendelson and Cole, 1972). A number of workers have proposed that initiation of division begins at about the same time as initiation of DNA replication, i.e., about $100 \mathrm{~min}$. before the division event at $30^{\circ} \mathrm{C}$ (Pierucci and Helmstetter, 1969; Shannon, Spratt and Rowbury, 1972; Jones and Donachie,

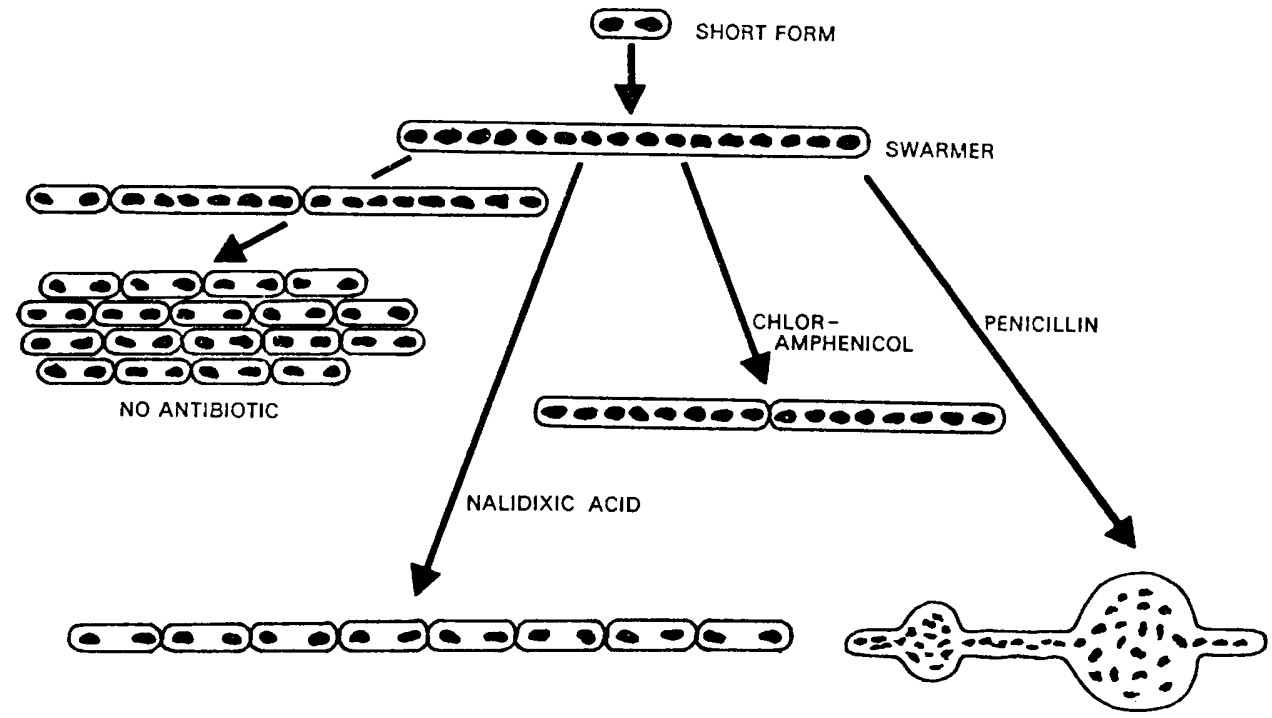

Fig. 9.-Diagrammatic summary of morphological changes in Proteus swarmers placed on agar with and without antibiotics.

1973). If cells in a swarm were unable to initiate division, the resulting filaments would probably take about $100 \mathrm{~min}$. at $30^{\circ} \mathrm{C}$ to divide when shifted to favourable conditions. In fact the first divisions occur within 15-30 min. In any case the initiation of division is probably merely the introduction of cell growth points that later become division points (Schwarz, Asmus and Frank, 1969; Ryter, Hirota and Schwarz, 1973). Clearly, growth points have been introduced in the swarmers since segregation of the nuclear bodies-which is ensured by the functioning of the growth points-has occurred normally.

Although the growth points seem to function normally in Proteus filaments they do not become septum growth points. Two general reasons appear possible. A protein or proteins essential for septum growth may be lacking. However, the occurrence of 2-4 divisions in the presence of chloramphenicol suggests that all division proteins are formed in the filament but that one or more may be unstable. Alternatively, a septum may fail to develop at a division 
point if swarmers are abnormal in the synthesis or structure of the envelope. Swarmer filaments do not generally lyse spontaneously so that a lesion in murein biosynthesis is unlikely and an apparently normal murein (R) layer can be seen in some sections of swarming filaments. Some subtle change in the murein cannot be ruled out but changes in permeability of the filaments (unpublished results) implicate the membrane as the probable site of the defect.

Swarmers failed to divide at all in the presence of penicillin which usually stops bacterial division immediately at low doses (e.g. Starka and Moravova, 1970; Leighton and Donachie, 1970) unless the cells have already completed their septa (Normark, Boman, and Bloom, 1971). The morphological changes in the swarmers provoked by the antibiotic were, however, most striking. The bulges formed were very large compared with those observed in studies with other organisms and were bounded by an envelope that appeared almost normal in the electron microscope. The failure of these cells to lyse when the bulges are smaller as in other bacteria may be related to the greater stability of Proteus to lytic agents in general (e.g., to lysozyme and EDTA; Gray and Wilkinson, 1965 ), or it may be that the osmotic pressure of the cells is lower. The penicillin-treated swarmer filaments become mis-shapen throughout and also seem to be fatter than the untreated filaments. The most striking observation however is that the normal segregation of nuclear bodies observed in the swarmer filaments is lost after a period of exposure to penicillin.

Thus the production of filamentous swarming cells in Proteus under " natural " conditions does not appear to be due to any failure of DNA synthesis or nuclear-body segregation. Neither does an abnormality in division initiation or a defect in murein synthesis seem likely. There remains the possibility that the cell membrane is altered in some way and that this interferes with septum formation and is also linked with the increased production of flagella. Studies on the protein and phospholipid composition of membranes from normal cells and swarming filaments are in progress. The nature of the signal that causes these changes in structure is not known.

\section{SUMMARY}

When filamentous swarming cells of Proteus mirabilis were observed on the surface of agar, they were seen to divide asynchronously into short cells. Inhibition of DNA synthesis with nalidixic acid had no effect on the division for about 2 hours which allowed time for the potential number of divisions to occur. Inhibition of protein synthesis with chloramphenicol allowed only 2 or 3 divisions and division stopped after 45-60 min. Inhibition of murein synthesis with penicillin stopped division immediately, but elongation continued for $30-45 \mathrm{~min}$. The cells then began to bulge and burst and there was disorganisation of the nuclear material. The implications of these observations with regard to the mechanism of production of swarming filaments in Proteus are discussed and it is concluded that a lesion associated with the swarming character is probably in the cell membrane.

One of us (J.P.A.) acknowledges the support of a Science Research Council Studentship. 


\section{REFERENCES}

Gray, G. W. AND Wilkinson, S. G. 1965 . The effects of ethylenediamine tetra-acetic acid on the cell walls of some Gram-negative bacteria. J. gen. Microbiol., 39, 385.

Helmstetter, C. E. AND PIERuCCI, O, 1968. Cell division during inhibition of deoxyribonucleic acid synthesis in Escherichia coli. J. Bact., 95, 1627.

Jones, H. E. AND PARK, R. W. A. 1967. The short forms and long forms of Proteus. J. gen. Microbiol., 47, 359.

Jones, N. C. AND Donachie, W. D. 1973. Chromosome replication, transcription and control of cell division in Escherichia coli. Nature New Biol., 243, 100.

KellenBerger, E., RYTER, A. AND SÉCHAUdT, J. 1958. Electron microscope study of DNAcontaining plasms. II. Vegetative and mature phase DNA as compared with normal bacterial nucleoids in different physiological states. J. biophys. biochem. Cytol., 4, 671 .

Leighton, P. M. AND Donachie, W. D. 1970. Deoxyribonucleic acid synthesis and cell division in a lon- mutant of Escherichia coli. J. Bact., 102, 810.

Mendelson, N. H. AND Cole, R. M. 1972. Genetic regulation of cell division initiation in Bacillus subtilis. J. Bact., $112,994$.

Normark, S., Boman, H. G. AND Bloom, G. D. 1971. Cell division in a chain-forming env $A$ mutant of Escherichia coli K. 12. Fine structure of division sites and effects of E.D.T.A., lysozyme and ampicillin. Acta path. microbiol. scand. B, 79, 651.

PierucCi, O. AND Helmstetrer, C. E. 1969. Chromosome replication, protein synthesis and cell division in Escherichia coli. Fedn Proc. Fedn Am. Socs exp. Biol., 28, 1755.

Ryter, A., Hirota, Y. ANd Schwarz, U. 1973. Process of cellular division in Escherichia coli. Growth pattern of E. coli murein. J. molec. Biol., 78, 185.

Schwarz, U., Asmus, A. AND Frank, H. 1969. Autolytic enzymes and cell division of Escherichia coli. J. molec. Biol., 41, 419.

Shannon, K. P., Spratt, B. G. AND Rowbury, R. J. 1972. Cell division and the production of cells lacking nuclear bodies in a mutant of Salmonella typhimurium. Molec. gen. Genet., 118, 185.

Smith, D. G. 1972. The Proteus swarming phenomenon. Sci. Prog., Oxf. 60, 487.

Starka, J. AND Moravova, J. 1970. Phospholipids and cellular division of Escherichia coli. J. gen. Microbiol., 60, 251. 